\title{
The Implementation of the Indonesian Adiwarna Design Concept Towards the Acoustics of Auditorium Tanah Airku Theater TMII Jakarta
}

\author{
Monica Monica $^{1 *}$ Ika Yuni $^{2}$ Fivanda Fivanda ${ }^{1}$
}

\author{
${ }^{1}$ Interior Design Study Program, Faculty of Art and Design, Tarumanagara University \\ ${ }^{2}$ Interior Design Study Program, Faculty of Art and Design, Kesenian Jakarta Institute \\ *Corresponding author. Email: monica.615170013@stu.untar.ac.id
}

\begin{abstract}
The advance of technology recently brings a positive impact for interior design. One of them is the design of a multifunctional auditorium. As a public entertainment place, the acoustics system is highly considered in designing an auditorium. To design a comfortable acoustic auditorium, required an interior acoustic system that can control and present an expected acoustic for a room. The acoustic finishing material has a great role in controlling and presenting an acoustic. Besides presenting an audial convenience, each acoustic finishing material used also needs to be adjusted to the image and design concept of the auditorium itself. In terms of colour and shape of the material as well. The acoustic material finishing is also corresponding to the placement of other acoustic materials in order to visualise the harmonization between the beauty of visualization and audial convenience in an auditorium.
\end{abstract}

Keywords: Acoustic, auditorium, convenience, implementation, theatre

\section{INTRODUCTION}

Along with the development of times and technologies that exist by today, the interior design sector gains a great positive impact. The design of an acoustic system is one of the systems in implementing various interior elements in a space. In this study, the room appointed is a multifunctional auditorium or performance room. The word auditorium comes from the word "audience" that is defined as a listener, viewer, an observer, and continued by the word room is a place. Therefore, an auditorium can be defined as a room to hear and see [1]. Broadly speaking, the auditorium space is divided into two parts, namely the stage zone for performance performers and the audience seat zone. The auditorium is classified into several groups based on function, location, basic plan feature, the basic shape of the cut. Based on its function, the auditorium can be divided into a meeting auditorium, arts auditorium, and multifunctional auditorium. A meeting auditorium typically includes a lecture hall, seminar room, meeting room, convention room, conference room, conference room, speech room, and sermon room. Then the art auditorium usually has a space size that is not too large with an open stage and a smaller stage area than the auditorium music and motion. The types of space for an art auditorium are a concert hall and a recital studio for chamber music performances, solo recital jazz, and poetry. Meanwhile, the art auditorium for music and motion has the characteristics of a large enough space, the original condition of a closed stage with a fairly large stage area and a type of space consisting of a theater space for opera, drama and dance performances. As well as a cinema for film screenings. Then based on location, the auditorium is divided into indoor, outdoor, and semiindoor auditoriums. The indoor auditorium has an auditorium function in the form of meetings, arts, or multifunctions. Acoustic quality is also easier to control, as well as located in the building. The outdoor auditorium has existed since the 4th century BC during the heyday of Rome. Auditorium functions for art with acoustic qualities tend to be more difficult to control, and are located outside the building. The semi-indoor auditorium has a characteristic where the performers are in an open space on the part facing the audience, and the audience is in an open space [1].

Then based on location, the auditorium is divided into indoor, outdoor, and semi-indoor auditoriums. Next is the basic plan form. The basic plan forms are distinguished by their stage design. Namely a closed stage, an open stage, and an arena stage. Closed stage usually Most or all of the stage is in space, the area of the stage is not limited by the audience seat layout with a low level of interaction between players and spectators. The open concert auditorium has a characteristic where most or all of the stage is in the audience zone, the stage area is limited by the seat layout, with the addition of a sound system. With 
the form of a curved stage, rectangle, trapezium, hexagon, or combination. An auditorium with an arena stage has the characteristic of having the entire stage in the audience zone, generally in the middle of the auditorium. Usually used for a concert hall or studio recital. The stage area is limited by the audience seat layout, it is not equipped with layer replacement facilities, but the level of interaction between the players and the audience is high. Then for the basic shape of the auditorium pieces can be divided into three and differentiated based on the audience floor design and ceiling design. Namely horizontal seating, reflective shell, raked seating. Of the three basic shape classifications of the auditorium cut above, the best for creating acoustic quality is raked seating with sound characteristics that are not hindered by the audience, there are reflectors and the sound can be evenly loud. In addition, design really supports the acquisition of good acoustic and visual quality.

Based on the above classification, The Tanah Airku Auditorium is classified as a multifunctional auditorium [2]. The entire multifunctional auditorium, its room is designed in order to fulfill several functions that have been planned. One of which is to accommodate various activities carried out in the auditorium such as recital activities, theater performances, or as a concert hall, so that it requires flexibility in accommodating various audible ranges of frequency Apart from being a provider of performance venues, Teater Tanah Airku also acts [2]. As a public entertainment place that provides the beauty of visualization related to Indonesia's natural and cultural wealth and audial convenience as well, it obviously has something to be considered namely the acoustic system. To design an acoustic auditorium system that is comfortable and attractive for its users, required an acoustic system that can control and present expected acoustic for a room and also the implementation of interior elements towards that acoustic system so that the users' audial and visual can be realized [3].

\section{METHODS}

This study used qualitative research and descriptiveanalytic methods. This method aims at describing or providing a framework towards the object of the study through data or samples that have been collected as is without analyzing and making general conclusion. The data collection process was conducted by doing an observation based on a personal source for the design is a document from the author. The collected data used as a reference for this study. The data processing technique is carried out by determining the needs for acoustic function for each interior element and determining acoustic materials namely absorber, diffuser, and reflector which will be implemented to interior elements in this design [3]. Acoustic material that has been selected and determined according to needs will be implemented to interior elements such as walls, floors, and ceilings.

\section{FINDINGS AND DISCUSSIONS}

\subsection{Design Objects and Locations}

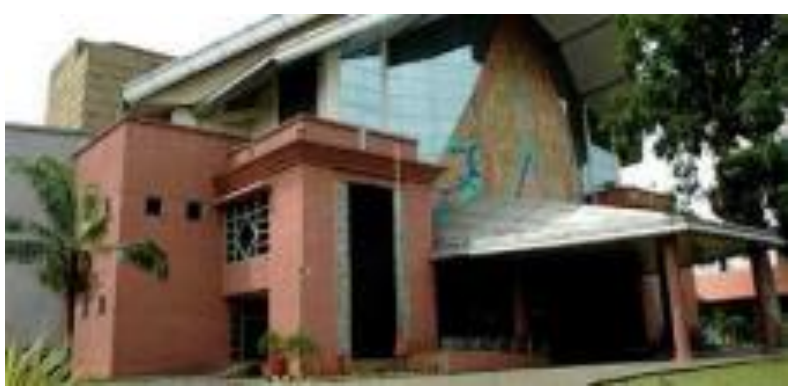

Figure 1 The facade of Tanah Airku Theater Building (Tanah Airku Theater Management)

Tanah Airku Theater is located in Taman Mini Indonesia Indah, Ceger, Kec. Cipayung, Kota East Jakarta, Special Capital Region of Jakarta 13820. Teater Tanah Airku was founded on April 20, 1998 and is a theater that was founded in Taman Mini Indonesia Indah which is a replica of the Indonesian state. Teater Tanah Airku is also the first theater to use media technology in its auditorium. The theater building was also inaugurated by the second president of Indonesia, Mr. Soeharto. The form of the Tanah Airku Theater building combines traditional and modern architectural elements, blending harmoniously and artistically. The roofs are inspired by traditional Sumatran and Sulawesi roofs, while the decorations combine elements of the archipelago with global culture. At the front, there is a variety of Javanese gunungan decoration flanked by Toba Batak traditional decorations and dragon and hornbill decorations that represent Dayak culture. Meanwhile, the side walls of the building are filled with a variety of typical Eastern Indonesian culture. Teater Tanah Airku also holds a strong vision and mission and is closely related to the design aspects of the building design. Its vision is to Introduce Culture and Natural Wealth to the Indonesian Nation and other Nations, to develop productive and efficient culture as a source of inspiration for the nation's civilization. Its mission is to provide healthy and comfortable tourism and education facilities. Improve the quality of the collection of culture, flora and fauna of the archipelago. This design is focused on the Tanah Airku Theater Auditorium. Which has a capacity of 1200 spectators. The Tanah Airku Theater Auditorium is an indoor auditorium. So that the acoustic quality is easier to control because of the small environmental influence. In addition, the Teater Tanah Airku auditorium is a multifunctional auditorium that accommodates various activities. Such as music performances, theater, meetings and concert halls. The Tanah Airku Theater Auditorium also has a design of open stage where most of the stage is in the audience zone and the stage area is limited by the audience seat layout and can be equipped with a stage screen replacement facility. The open stage design has a high level of interaction with the audience. The more open 
the stage, the higher the level of interaction between the players and the audience.

\subsection{Design Concept}

The acoustic design of this auditorium is formed and designed according to the function of the auditorium itself [4]. Teater Tanah Airku designed its auditorium space as a multifunctional auditorium. Thus, acoustic design is designed to be more flexible in order to accommodate a variety of existing sound frequencies [1]. Of all the sound frequencies we can hear, there are six frequencies that can be used in designing auditorium acoustics. The appropriate sound frequency for an auditorium can be determined based on the main function of the auditorium space. As a multifunctional auditorium, the average sound waves that can be accommodated in the $500-1000 \mathrm{~Hz}$ range. Music sound frequency range is greater than conversation. A musical instrument is an example of a sound source that has a regular frequency. In a show, if several musical instruments are played, the frequency of the dominant type of musical instrument will be heard. With a maximum delay time of $1 / 20$ seconds or 0.05 seconds [1]. The delay time is the amount of time it takes between the original sound and the reflected sound. In order for the delay time to be as needed, it is very important to keep the reflected sound from traveling too long for the audience to accept. This means that the dimensions of the auditorium space must have the right proportions, not too high, not too wide, and not too long. To fulfill the need for good acoustics in the auditorium, the acoustic system will be applied to interior elements, namely on walls, floors and ceilings [5]. With the composition of the use of material absorber 35\%, reflector $45 \%$, and diffuser $20 \%$. The composition above is used for a capacity of 1200 spectators. The placement of each material is also divided into its application to interior elements. The absorber has a higher sound absorption capacity than its reflection power. Generally, it has a soft and porous material texture. The absorber is installed on the opposite side wall, the back wall of the auditorium, and the floor audience. The reflector has a higher sound reflectance than absorption. Generally, it has a hard and slippery texture. For reflector material, the thicker the feeding material the better the reflection. The reflector is installed on the front wall (stage zone) facing the audience and the ceiling. Then, the diffuser or spreader is a reflector or absorber with an irregular arrangement. With the sound absorption coefficient depending on the material. Generally, it has a hard and slippery texture. Its placement of the resembles the application of an absorber, namely on the opposite side wall and the opposite stage wall. After determining the placement of the acoustic materials above, the next step is to provide the material finishing. The finishing on the acoustic system that has been implemented on the interior elements uses materials that are in accordance with the design concept of this auditorium, namely Adiwarna Indonesia. The finishing material on the walls and ceiling that functions as a reflector is dominated by the use of High-Pressure Laminate brown (HPL) and tufted wall panels. While the wall finishing material that functions as an absorber, uses rockwool material which has a density of $60-10 \mathrm{~kg} / \mathrm{m}^{3}$. On the floor, the finishing material is dominated by the use of carpets for the zone of audience which functions as an absorber and vinyl flooring for the performer zone to function as a reflector and make it easier for the players to move on the stage.

\subsection{Form Concept}

Use of interior concepts is supported by the location of the Tanah Airku Theater. As we know Teater Tanah Airku is located in Taman Mini Indonesia Indah which is a miniature from Indonesia. Thus, the concept raised is a concept that is thick with Indonesian culture. The first concept adopted as a representative of Indonesian culture is kawung batik. Kawung batik is one of the most famous batik motifs from Yogyakarta. This motive is shaped like a circle resembles kawung fruit or palm fruit arranged geometrically. In Javanese culture, the kawung motif which is arranged geometrically is interpreted as a symbol of the occurrence of human life. The hope is that humans will not forget its origin. In addition, the motif kawung is also known as a symbol of courage and justice. Kawung batik motif is applied to the sidewall facing the auditorium. The place where the absorber is rockwool at the finishing with High Pressure Laminate. On the wall there are several cavities (the HPL in a hole) that is useful so that the sound is scattered and not fully reflected because of the use of HPL on surfaces. The cavity in the wall is formed by taking the geometric shape from the kawung batik motif above. Next is a geometric shape made of bamboo Betawi, or commonly known as the jalusi. This motif is often encountered in Betawi-style houses. Jalusi itself functions as an air circulation gap. This jalusi motif was applied to the side wall facing the auditorium. More precisely this motif is under the kawung batik motif. This jalousie motif is applied to the tufted wall panel with black synthetic leather which functions as an absorber sound. The final form concept used and applied in the auditorium is the form of archipelago. Archipelago is a sea area with islands in it. So that archipelago always means an archipelago or a collection of islands. The shape adapted from the archipelago is the waveform of the islands. Then the shape was transformed into a more modern geometric shape.

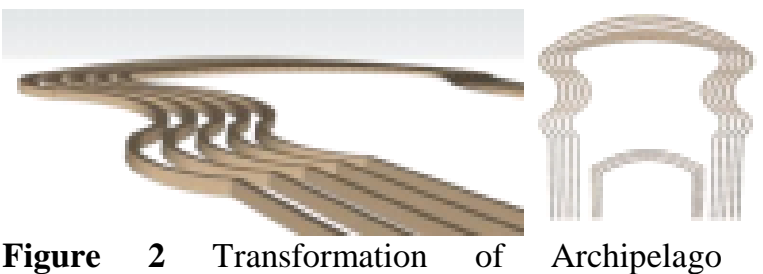

Figure 2 Transformation of Archipelago Indonesia's Form (Monica, 2020) 
From this transformed form it is only then applied to the auditorium. This form is applied to the auditorium ceiling. This form is finished using High Pressure Laminate which functions as a sound reflector in the auditorium ceiling.

\subsection{Implementation of Designs and Forms}

The designs and forms that have been obtained from the the exploration of the above design concepts, starting from the kawung batik motif, the geometric shape of the jalusi motif, and the archipelago shape are applied to the interior elements of the Tanah Airku theater auditorium. Whether it's on the floor, walls, and ceiling. Where all existing shapes and finishing materials have their own role in presenting good acoustic quality and visual beauty for the auditorium of the Tanah Airku Theater. The following are examples of implementing forms into designs:

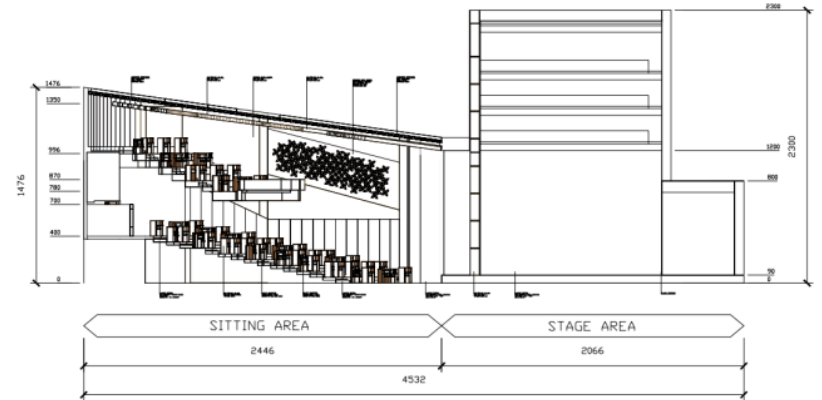

Figure 3 Implementation of design concepts in the auditorium cutout work drawings (Monica, 2020)

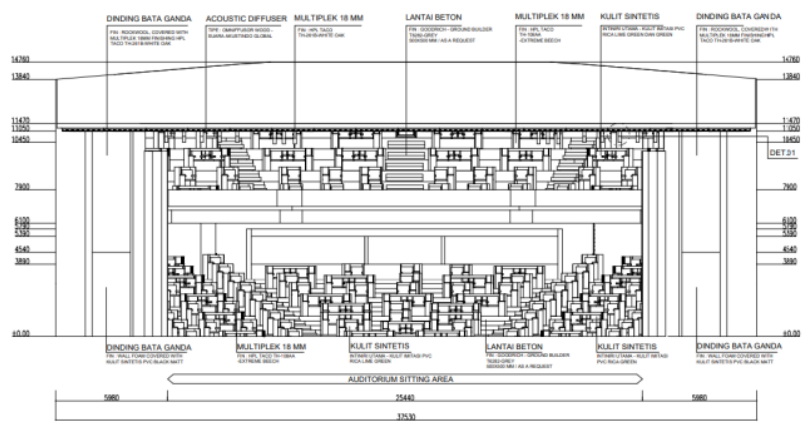

Figure 4 Implementation of design concepts in the auditorium cutout work drawings 2 (Monica, 2020)

Through the picture 4 and 5 , can be shown that the technical implementation of the design in this auditorium room. On the walls, the kawung batik geometric shapes are seen and there are decorative elements from the transformed
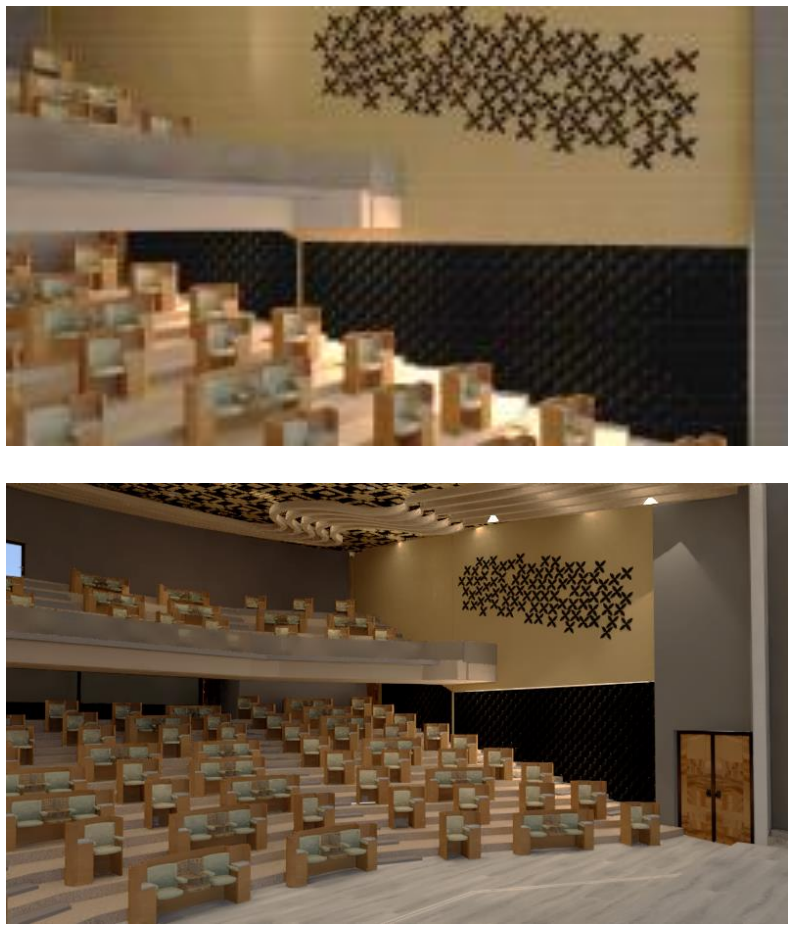

Figure 5 Implementation of the design of the kawung batik motif, jalusi geometric motifs on the walls.

(Monica, 2020)

Through the spatial perspective image above, it can be seen clearly the implementation of the kawung batik motif and the geometric jalusi on the auditórium wall. Keep in mind that the kawung batik motif on the wall is part of the surface of the wall that is perforated and open, where the rockwool material can be seen. So that the scattered reflected sound can be directly absorbed by the absorber material, namely the rockwool on the wall.

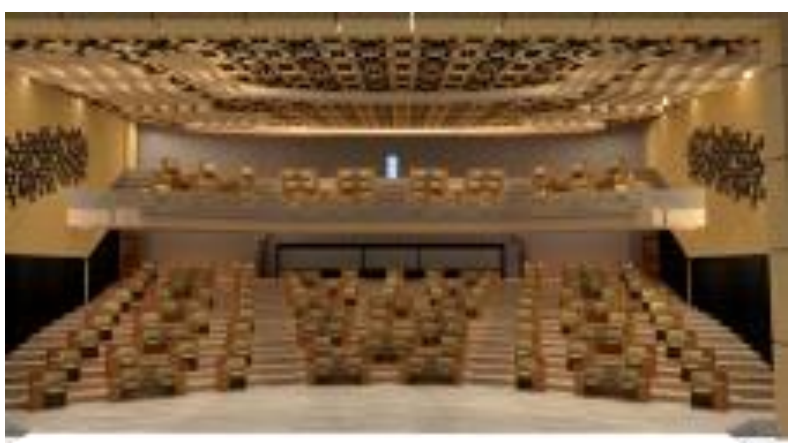




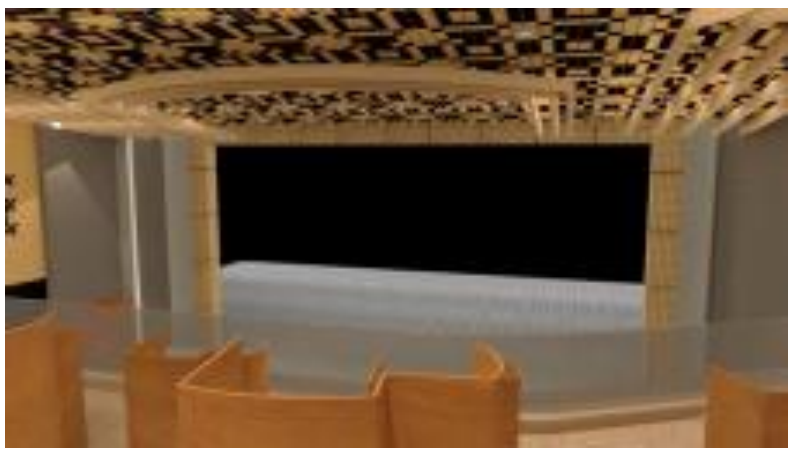

Figure 6 Implementation of design concepts in the ceiling auditorium (Monica, 2020)

Through the perspective image above, it can be seen clearly the implementation of the archipelago transformation design on the auditórium ceiling which is finished with brown high-pressure laminate and functions as an acoustic sound reflector. The ceiling in the form of archipelagic transformation is implemented by hanging it and not sticking to the ceiling surface. Meanwhile, the ceiling surface uses a diffuser material with an omniffusor type which acts as a sound spreader that is formed in the room.

\section{CONCLUSIONS}

In designing the Implementation of Interior Design Elements on the Acoustics of the Tanah Airku Auditorium, there are several things that need to be considered before carrying out the design. Such as the needs and functions of the auditorium to be designed, sound waves that can be accommodated by the auditorium, and the application of acoustic materials that can help create audial comfort for its users, such as material compositions that function as absorbent, reflective and acoustic spreaders. Once audial comfort is realized, visual beauty also plays an important role in this design. The application of finishing materials must also be in accordance with the image and design concept of the auditorium. Both in terms of shape and color of the material. The finishing material must also be adjusted to the placement of other acoustic materials, in order to create a harmonization between visual beauty and audial comfort in the auditorium. That is the subject of research that the author can explain. Hopefully this research can be useful for many people. Due to limited information and references, the authors realize this research is still far from perfect, therefore the authors provide suggestions so that the next researchers can take advantage of existing technological advances and can process data better with creative ideas to encourage design development for facilities. -One of the recreational facilities is the acoustic design of an auditorium. The author hopes that this research can be structured to be even better for the future.

\section{ACKNOWLEDGMENT}

The author would like to thank the parties who have participated and provided support and suggestions in preparing journals and also designing the Implementation of Interior Design Elements on The Acoustic of The Tanah Airku TMII Auditorium, Jakarta. Especially to Mr. Gufi as the manager of the Tanah Airku Theater building who helped during the compilation and processing of working images from Teater Tanah Airku. Then to family and friends who always support and faithfully wish the best for the success of this research. Finally, to all the mentors who have provided constructive criticism and suggestions. So that this research can be completed and successful. With the completion of this research, the authors would like to thank you. who helped during the compilation and processing of working images from Teater Tanah Airku. Then to family and friends who always support and faithfully wish the best for the success of this research. Finally, to all the mentors who have provided constructive criticism and suggestions. So that this research can be completed and successful. With the completion of this research, the authors would like to thank you.

\section{REFERENCES}

[1] L. N. Laela, Fisika Bangunan Jilid II, Jakarta:Griya Kreasi, 2015

[2] S. Judith, Theater buildings - a design guide, Routledge, 2010

[3] S. Prasasto, Architectural Acoustic, Jogjakarta: Andi, 2019

[4] H. Roderick, Theaters: Planning Guidance for Design and Adaptation, 2014

[5] S. Handoko, Prinsip-Prinsip Akustik dalam Arsitektur, Jogjakarta:Kanisius, 2015

[6] A. D. R. Sri, 2009, Tinjauan Akustik Perancangan Interior Gedung Pertunjukan, Imaji, Vol.7 
[7] I. Hedy C., 2004, Pengaruh Elemen Interior Terhadap Karakter Akustik Auditorium, Dimensi Interior, Vol.2

[8] N. A. W. Eko, 2018, Perancangan Interior Concert Hall Institut Seni Indonesia Yogyakarta Untuk Pertunjukan Musik, Institut Seni Indonesia

[9] N. Victoria, Site and Sound: The Architecture and Acoustics of New Opera Houses and Concert Halls, The Monacelli Press, 2012

[10] K. Lynne, R. David, Theatre Noise: The Sound of Performance, Cambrige Scholars, 2011

[11] D. Victoria, The Art of Theatrical Sound Design, Bloomsbury Academic, 2018 